GEOLOGICAL SURVEY CIRCULAR 110

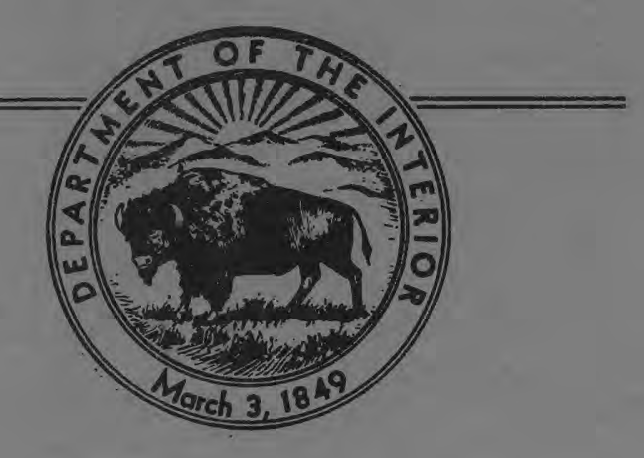

March 1951

\author{
PROGRESS REPORT
}

\title{
HYDROLOGY OF STOCK-WATER \\ RESERVOIRS IN ARIZONA
}

By

W. B. Langbein, C. H. Hains, and R. C. Culler 


\section{UNITED STATES DEPARTMENT OF THE INTERIOR}

Oscar L. Chapman, Secretary

GEOLOGICAL SURVEY

W. E. Wrather, Director

Washington, D. C.

Free on application to the Geological Survey, Wahington 25, D. C. 


\section{PREFACE}

Many agencies and individuals have alded materialiy in the stock-pond investigations. Most of the gaging installations are located on Indian reservations or in grazing districts where officlal employees have helped locate sultable reservolrs for study, sometimes providing tools and labor, and often arranging for the gathering of gage readings. Among those who have been especially helpful are $\mathrm{W}$. H. Berry, reglonal conservationlst, and Bernard Hodgin, engineer, Bureau of Indian Affalrs, Phoenix, Arlz.; Paul Buss, forest supervisor, and Kelth Douglass, conservationlst, San Carlos Indian Reservation; J. J. Schwarz, engineer, and William Fair, conservationlst, Navajo Indian Reservation; Ward Kindred, conservationist, Fort Apache Indian Reservation; V. D.
Smith, forester, Hualpai Indian Reservati on: and Clarence Kinkor, conservationist, Papago Indian Reservation. The services of these men are greatly appreclated.

The field work was carried out in the water Resources Division of the Geological Survey as part of the Soll and Molsture Conservation program of the Department of the Interior, under the supervision of H. V. Peterson, staff geologist, by C. H. Hains, hydraulic engineer, unt11 1949, and thereafter by R. C. Culler, hydraulic engineer. This report was prepared by $W$. B. Langbein, hydraulic engineer. G..B. smith, hydraulic engineer, assisted in the observations at Juniper Lake on August $5-6$, 1950 . 


\title{
PROGRESS REPORT
}

\section{HYDROLOGY OF STOCK-WATER RESERVOIRS IN ARIZONA}

By

\author{
W. B. Langbein, C. H. Hains, and R. C. Culler
}

CONTENTS

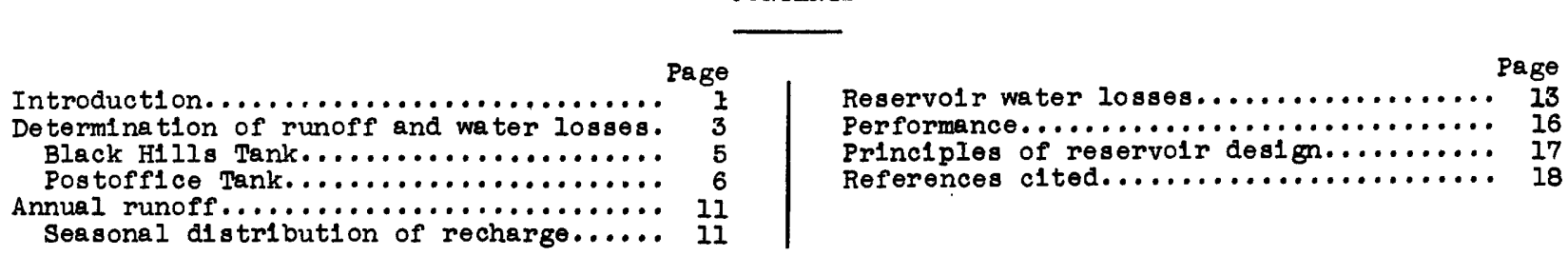

\section{IILUSTRATIONS}

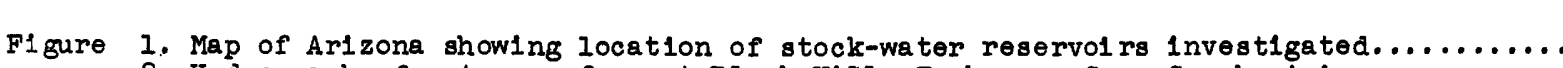

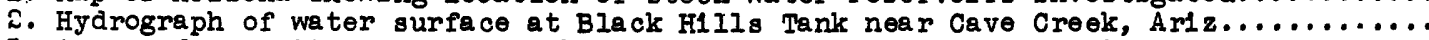

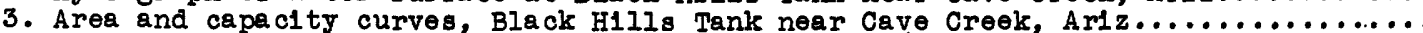

4. Area and capac1ty curves, Postoffice Tank near wh1 terlver, Ariz................

5. Hydrograph of water surface at Postoffice Tank near Whiteriver, Ariz., and monthly prec1pitation for average of Whiteriver and McNary, Arla.................

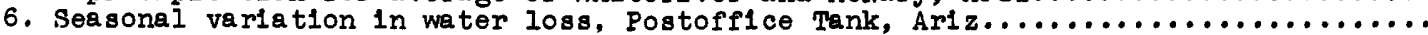

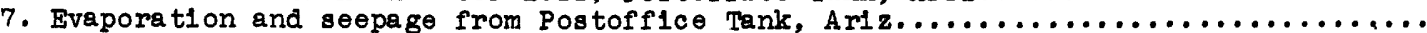

8. Relation of monthly recharge to precipltation, Postoffice Tank, Arlz...........

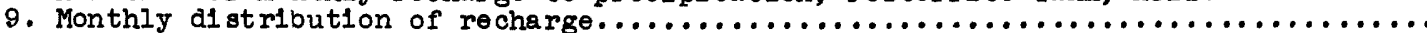

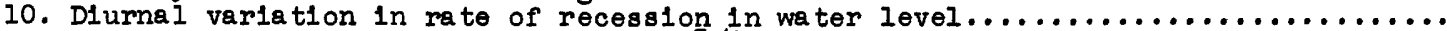

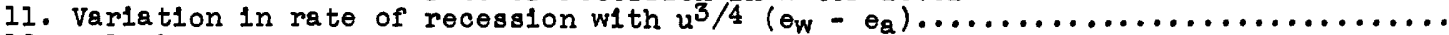

12. Relation of performance to munoff, water area, water loss, and frequency of

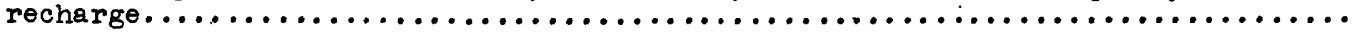

Table 1. Dry perlods, Postoffice Tank

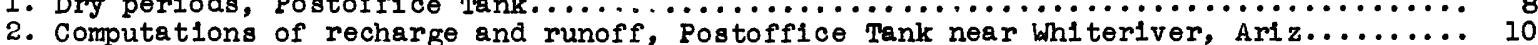

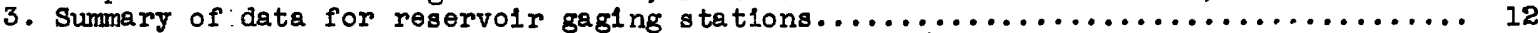

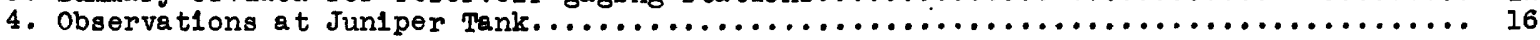

\section{INTRODUCTION}

The many thousands of stock-water reservolrs throughout the Western Range provide a liarge part of the watering facilities for the Nations lives tock industry. The individual stockwatering pond represents a small investment but the aggregate of all ponds is an investment of many million dollars.

Harvesting of the forage crop by stock on the Western Range depends on the accessibility of water. In general, cattle do not graze more than $3 \mathrm{mlles}$ from water. Where the water supplies are far apart, forage close to water is so intensively cropped that destructive erosion is Induced, whereas valuable forage at a distance remalns unharvested. Unt form and efflclent ut1lization of the forage requires a large number of water supplies only short distances apart. For this reason, many thousands of reservolrs have been bullt. A recent survey in the 9,000-square-mile basin of the Cheyenne River in Wyoming shows that there are nearly 10,000 reservolrs, or about one per square mile. Although this density of reservolrs may not apply throughout the Intermontane Plateau, it is nevertheless indicative of a high state of development in some areas. Consldering the constmaction under way and proposals for even greater construction, 1t 18 evident that the performance of stock-water 
reservolrs is a matter of great economic concern.

The avallability of a dependable supply of stock water at the proper time or times during the grazing seasons is of extreme importance to the range-livestock industry. In humld areas, rivers, creeks, natural ponds, or lakes provide dependable waters and providing stock water is no problem. At the other end of the scale are the many arid ranges that do not contain any "live" waters. Between these two extremes there are still other ranges where seasonal water may be avallable or where water must be artificially provided. The arld or semiarid range areas present a unique problem in range management to livestock operators. Under these circrumstances and conditions many and varied approaches to the solution of the water problem on such areas have been made.

Advantage is taken of the fact that water is a "key" resource on the arid range. Providing or withholding water for lives tock permits better management of range and the livestock., For example, such use of water as a control in many instances limits the necessity for construction and maintenance of costiy fencing projects. Water control, in Ileu of fencing, is being used more and more to provide protection for areas that have been reseeded or are in other ways being rehabilitated under the departmental so11 and molsture conservation program. Water control also permits range managers to provide for short-time water on lambing grounds, around loading stations adjacent to rallroad shipping points, or at shearing pens, In holding pastures or roundup grounds.

For the best operating practices, yearlong water is not always desirable in the management of range and stock on western range areas. Some ranges, because of the character of the forage, are usable to advantage only in the spring; others only in the fall; whereas st1ll others could be used for longer perlods, and in some sections of the west many ranges a re used the year long.

Attempts of stockmen and range managers to meet the problems that are frequently complicated during wet years or seasons of drought, have produced a varled pattern of stock-water developments and stock-water use. Lack of hydrologic and geologic data pertaining to watersupply possibilities has heretofore resulted in many unwise or impractical developments or attempts to provide water. Unfortunately some of these attempts that falled brought about considerable damage to the range or to values downstream. Better land and livestock management requires that improved practices be instituted. The Division of Land Utilization for the pest several years has been sponsoring studies of the problems involved for the purpose of providing sound geologi $c$ and hydrologic. pata to the land management agencles to enable them to manage the range lands more effectively and at a reasoneble cost.

Flow in the small drainage courses on grazr ing lands is infrequent and orratic. In order to provide carryover between storms, the tendenc $\mathrm{y}$ has been for the stockmen to make their reservolrs large, thus creating great surface areas and thereby increasing losses of water by evaporation and seepaige. It seems signtficant that the amount of water consumed by stock from the ordinary reservolr is only a small fraction of the total flow in the washes; most of the water is lost by evaporation or di sappears by seepage.

An important problem in water conservation is to minimize waste by permitting the surplus waters to flow downstream for the benefit of other users and for useful native vegetation. The solution of this problem depends largely on adequate data on runoff and sedimentation in the "dry" washes in the semiarid and arid parts of the country. Hydrologi c information in the desert areas is needed not only for deslgning stock-water reservoirs but for determining source areas of flow in the major streams and of ground-water recharge. The flow in the dry washes is too erratic and the channels are too unstable to justify operation of stream-gaging and sediment stations. Gageheight records on dry washes can be obtained by "kickoff recorders" (triggered by a flow of water), but dependable discharge ratings are difficult to define on these ephemeral streams. Obtaining discharge measurements and sediment samples on washes of this kind would require the full-time residence of a hydrographer, entaliling costs too high to warrant the work except perhaps on an intensive experImental scale.

In 1944 and 1945 , in connection with reservolr performance studies, gages were installed on several stock-water reservolrs. The initial purpose was to learn when the reservolrs contained usable water, the rate of $108 \mathrm{s,}$ and the frequency and amount of replent shment-- the chief factors that determine the success or fallure of a reservolr. Later it was found that the records of water level could also be interpreted in terms of the runoff into the reservolr. A group of reservolrs in Arizona, where they are commonly called "tanks" by stoclmen, was selected for these inltial studies (see flg. 1). Bnameled gage plates graduated to 0.02 foot were installed on posts in the bainks of the reservolrs. As most of these reservolrs are at locations remote from ranch houses or routes of frequent travel, the best that could be done was to obtain weekly readings. Neverthelese, readings were uncertain, and gaps of several weeks are numerous In the records. These gaps, al though vexing, were not crltical because for many months the reservolrs were slowly receding and 1 t was not difficult to plece out the record. Spliling was more troublesome, except for those reservolrs with sufficlent capacity for overflow to be infrequent. Experience in Arizona indicates that reservolis with a capacity of 10 acre-feet or more per square mile of dralnage area are best sulted to stock-reservolr studies. Reservolrs of this size are also sufficiently large to trap all the sediment carried by the Inflow.

It was found that records of this kind could jield considerable information in comparison with their cost. From the record of fluctuations of water levels, data on runoff, seepage, and evaporation can be obtalned. Repeated capacity surveys provide information on volumes of sediment carried by the floods in the dry washes.

It is belleved that the stock-reservoir studies begun in Arlzone w1ll help relleve the shortage in hydrologic data for the arid country. The studies have since been expanded to include a few basins in Wyoming, Colorado, and 


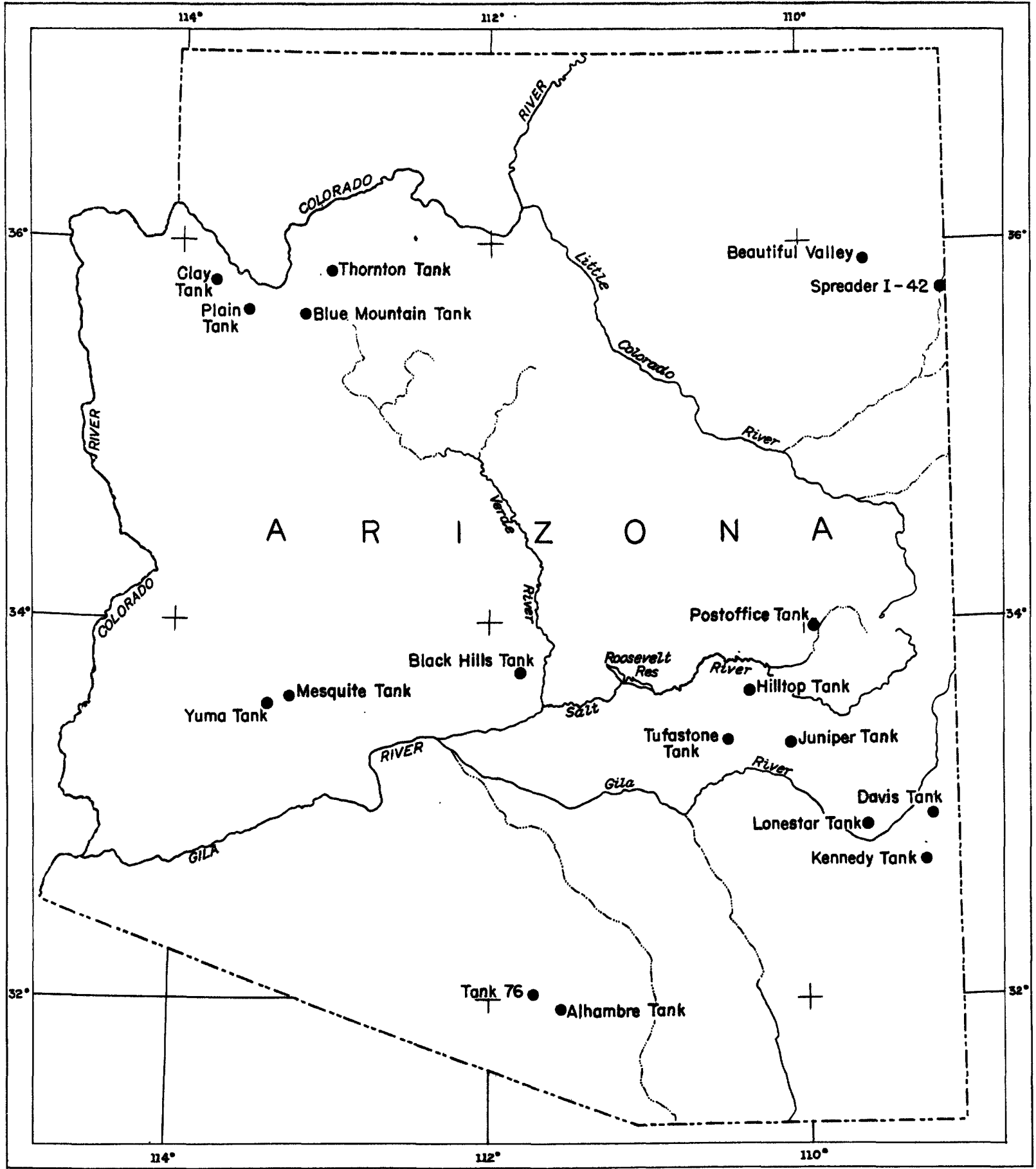

Figure 1.--Map of Arizona showing location of stock-water reservoirs investigated.

Utah. It is planned, at these new sites, to study sedimentation and erosion as well as runoff. This report, however, will be confined to performance at the original Arizona installations; but when longer periods of record are avallable, later reports will include the additional sites. This investigation was directed mainly toward evaluation of reservolr perforinance; problems of design or construction of dams were not included, nor were any studies made of flood discharges or spillway design.

\section{DETERMINATION OF RUNOFF AND WATER LOSSES}

The common type of ary wash in the arid country carries flows only as a result of the more intensive summer storms. The stream rise is rapid, sometimes as a wave front advancing downstream. The peak is sharp; the stream 


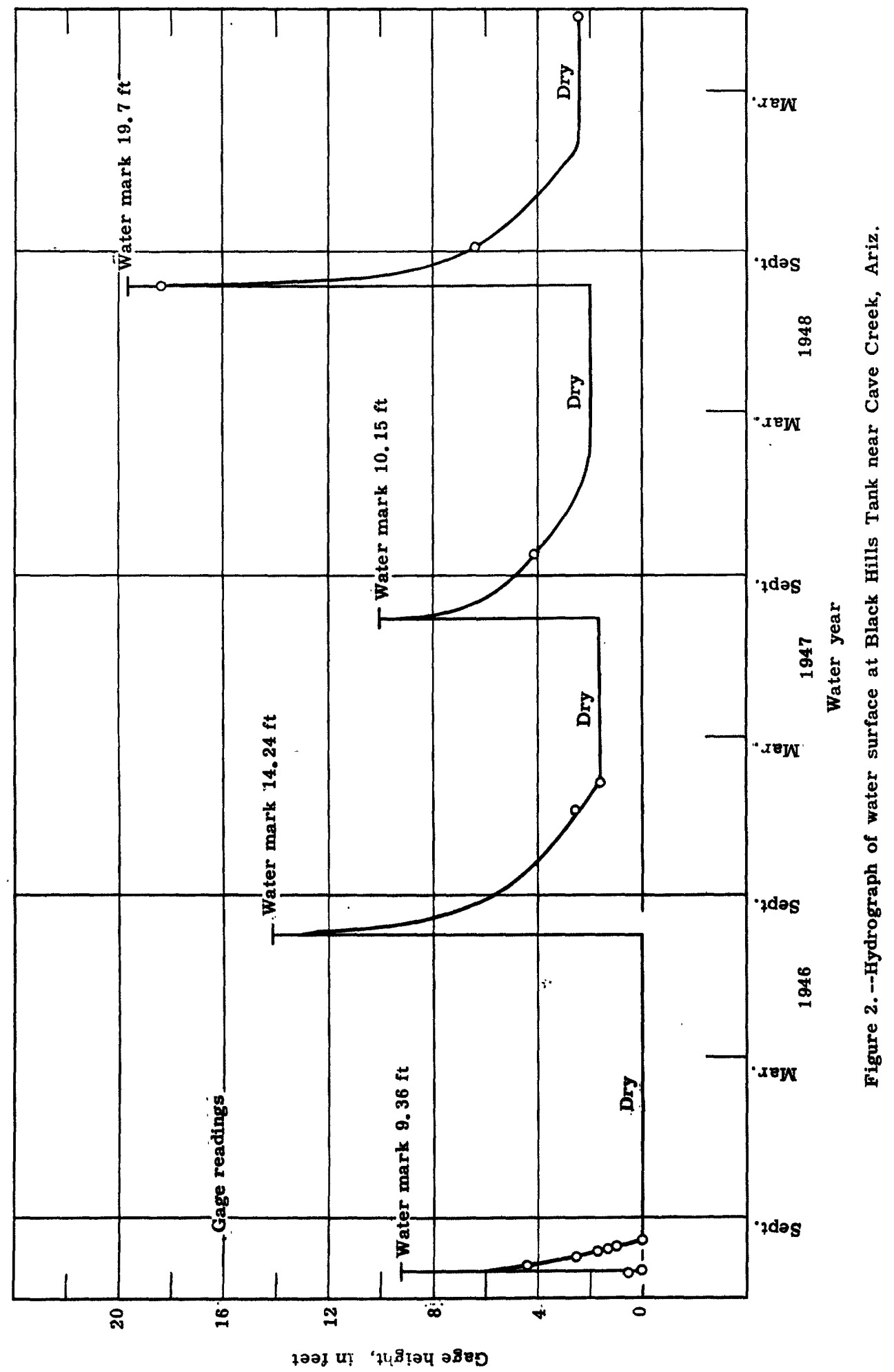


recedes quickly; and the channel may be dry again within a few hours.

When this flow is impounded by a stock-water reservoir, there is a rapid rise in stage until the inflow cerses. The duration of inflow is so short thet seepage and evaporation Iosses from the reservol $r$ may be a ssumed to be negligible during the period. Hence the total volume of flow may be closely determined by the increment in volume in the reservoir. After inflow ends, the stage in the reservoir begins to decline, rapidiy at first and then more slowly as the seepage rate becomes leas. If inflow does not recur for some time, the reservolr may go. dry.

Records of water Ievels were obtained for 18 reservolrs in Arizona. The method of analysis is illustrated in this report by two examples; the first is typical of performance in the arld country and the second of the more humid mountainous country.

\section{Black Hilis Tank}

Black Hills. Tank near Cave Creek, Maricopa county, Ar1z., is typical of a reservolr in the desert. The climate at this reservoir is similar to that of the valleys of the lower Gila Basin and west-central Arizona. Annual rainfall averages bout 8 inches and annual temperature $70^{\circ} \mathrm{F}$. A study of rainfall records obtained at Camelback, Arlz., 17 miles southwest of the reservol $r$, shows that rainstorms in excess of 0.5 inch per dey average only 3 for a year.

The reservoir is formed by an earthfill dam, 28 feet high across a dry wash approximately $2 \frac{1}{2}$ miles long, and has a total capacity of about 65 acre-feet. The reservolr intercepts the runoff from an area of 1.56 square miles that is drained by a network of small washes 6 inches to 2 feet deep draining to the southeast on a slope of about 2 percent. The granitic rock that underlies the besin is capped by a thin mantle of coarse residual soll. Vegetation is of the mountain-brush type, consisting mainly of snakeweed, yucca, creosote bush, cactus, and small paloverde trees. Mesquite grows along the main drainage channels. The altitude (determined by aneroid barometer) ranges from 2,600 feet at the reservoir to 3,200 feet at the head of the basin.

The hydrograph of water levels in the reservoir, as constructed from gage readings and high-weter marks, is shown on figure 2 . OnIy one period of inflow occurred in each year of record. Because of the infrequency of rainstorms of sufficient volume and intensity to produce runoff, and particularly because of the perviousness of its bottom, the reservolr is dry more than half the year. The volumes of munof associated with each rise in the reservoir, which occurred in August in every year listed, are as follows:

Date

Runoff in acre-feet
The 4-year average runoff is 13.5 acre-feet-8.5 acre-feet per square mile or 0.16 inch.

The results of capacity surveys are shown on figure 3. The original capacity in 1945 below a stage of 19 feet was 30 acre-feet. A resurvey in June 1949, when the reservolr was dry, showed a capacity of 26.5 acre-feet, indicating a 4-year deposition of 3.5 acre-feet, most of which was located below a stage of 10 feet. The original low point was at a gage height of zero, but in June 1949 the bottom was at a gage height of 2.4 feet. The year-toyear rise in the bottom is shown by the hydrograph on figure 2. About half of the sediment accumulated was produced by a small debris wave that accompanied the runoff of August 1948. A field examination shortly thereafter showed that this wave deposited 2 -foot mud clods, 6-inch rocks, and whole mesquite trees in a fan at the entrance to the tank; but only fine sediments reached the bottom of the reservoir.

The record shows, therefore, that in addition to the average annual water minoff of 13.5 acre-feet, there was sediment amounting to 0.9 acre-foot per jear $(0.55$ acre-foot per square mile per jear), or 6 percent by volume of the runoff.

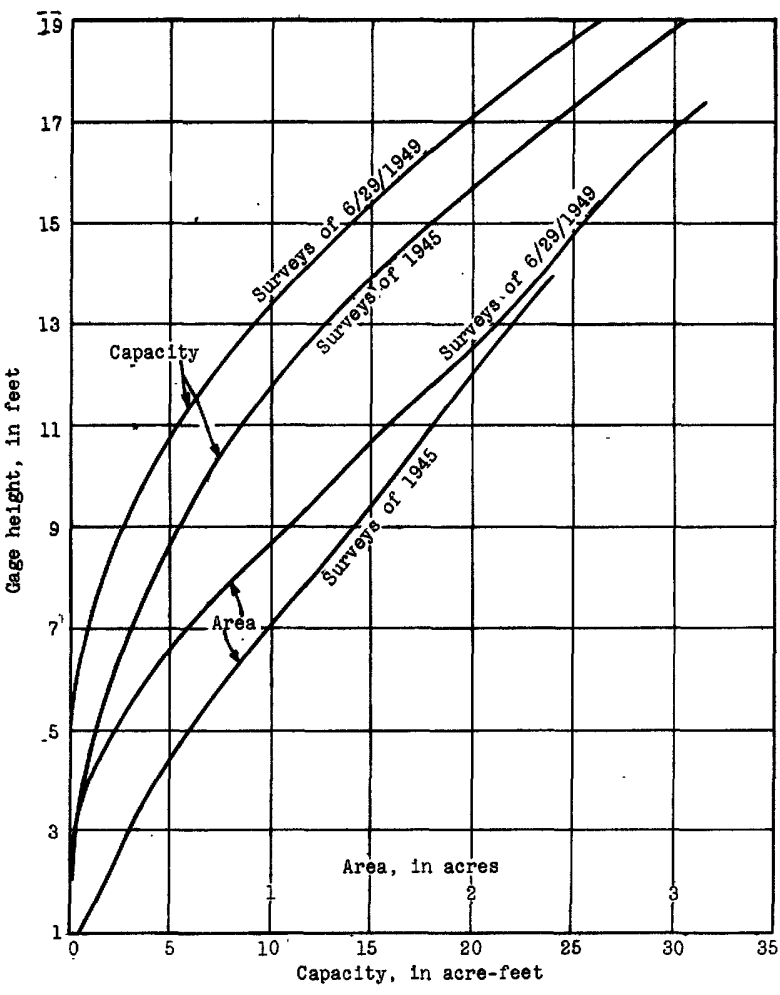

Figure 3..- Area and capacity curves, Black Hilis Tank near Cave Creek, Arla 


\section{Postoffice Tank}

A quite different analysis must be made of the records on reservolrs that contain perennial or more nearly perennial weter. In general, the fluctuation in water level of a reservolr is given by the equation:

$$
\Delta \mathrm{H}=\mathrm{R} / \mathrm{A}+\mathrm{P}-\mathrm{E}-\mathrm{S}-\mathrm{U} / \mathrm{A}
$$

in which $\Delta H$ represents change in water level

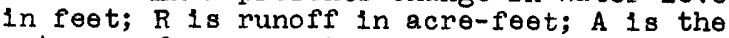
water-surface area in acres; $P$ is precipitation on the pond surface in feet; $E$ is evaporation in feet; $S$ is seepage in feet; and the term U/A represents the effect of use by livestock, expressed also in feet. The sum of the inflow terms $R / A+P$ is called recharge, and the sum of the terms $E+S$ is called water loss. The observed data are $\Delta H, P$, and $A$; the problem is to determine the values of $R$, $E$, and $S$. For most reservolrs utilization of the water by stock is relatively small, amounting to 0.3 acre-foot or less per year.

Postoffice Tank near Whiteriver, Ariz., on the Fort Apa che Indian Reservation, is an example of a perennial reservolr. This reservolr

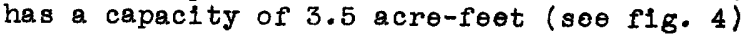

Impounded by an earth dam about 11 feet high. The reservoir intercepts the runoff from a drainage area of 0.29 square mile on the Mogollon Rim. The drainage course lies in a canyon that runs parallel and adjacent to Postoffic canyon and is separated from that canyon, as well as from the dralnage area on the south, by ridges with side slopes of 25 percent. The altitude at the dam is 5,725 fe日t above mean sea level. (by aneroid berometer) and the drainage basin heads on a mountain peak 500 feet higher. The sandstone that underlies the basin is mantled by a fairly thick sandy soll containing boulders and cobbles. The fill in the canyon bottom is falrly thick and coneists of sandy loam. The basin iles in a dense pine forest with much litter. Very little evidence of recent erosion is noted, except for minor washing of the main channel near the reservoir.

The hydrograph of water levels in this reservolr, based on weokly readings on a staff gage, is shown on figure 5. It may be observed that the hydrograph consists, in the main, of abrupt rises in stage caused by runoff followed by slow depletions due to evaporation and seepage. However, recharge is frequent and the water supply is perennial. There are

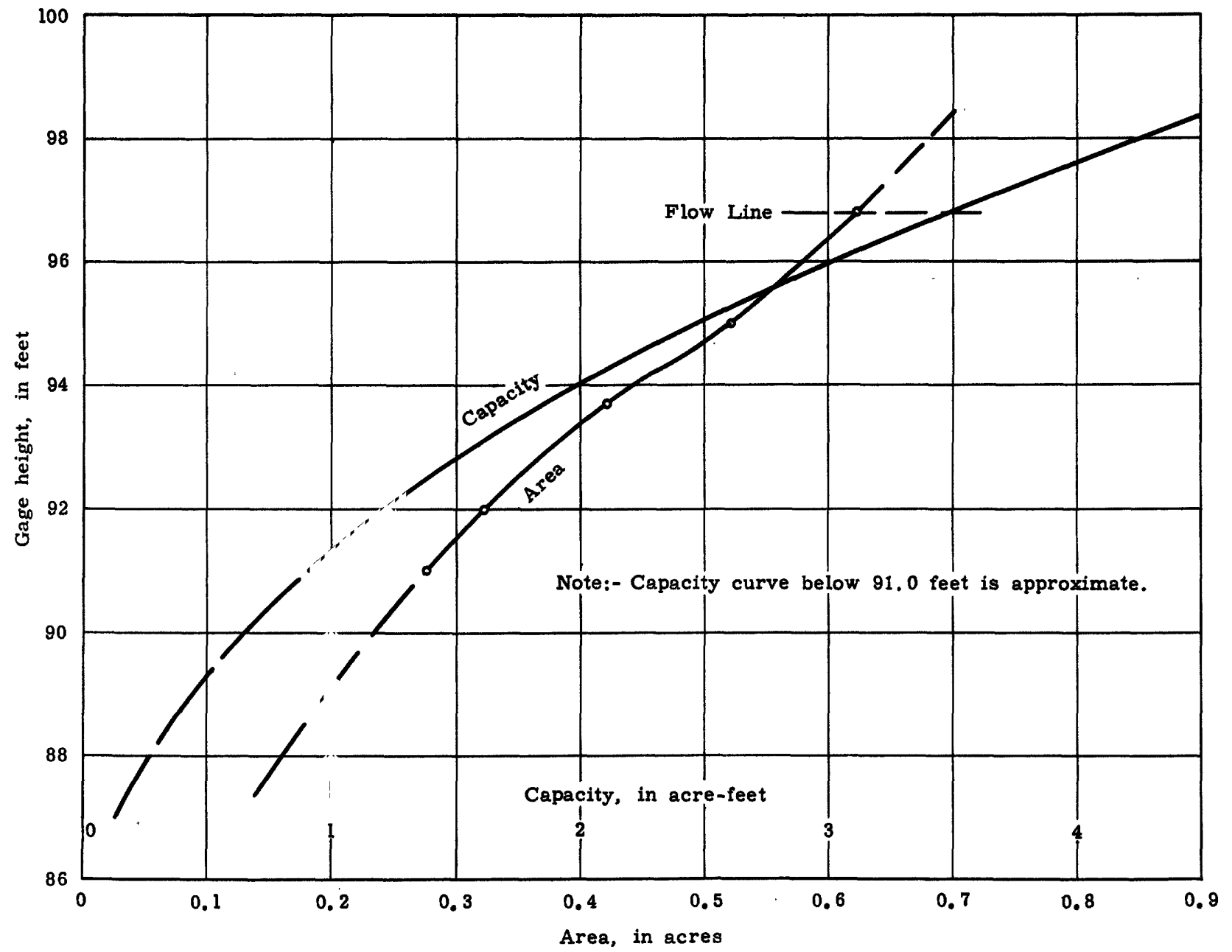

Figure 4.-- Arøa and capacity curves, Postoffice Tank near Whiteriver, Ariz. 


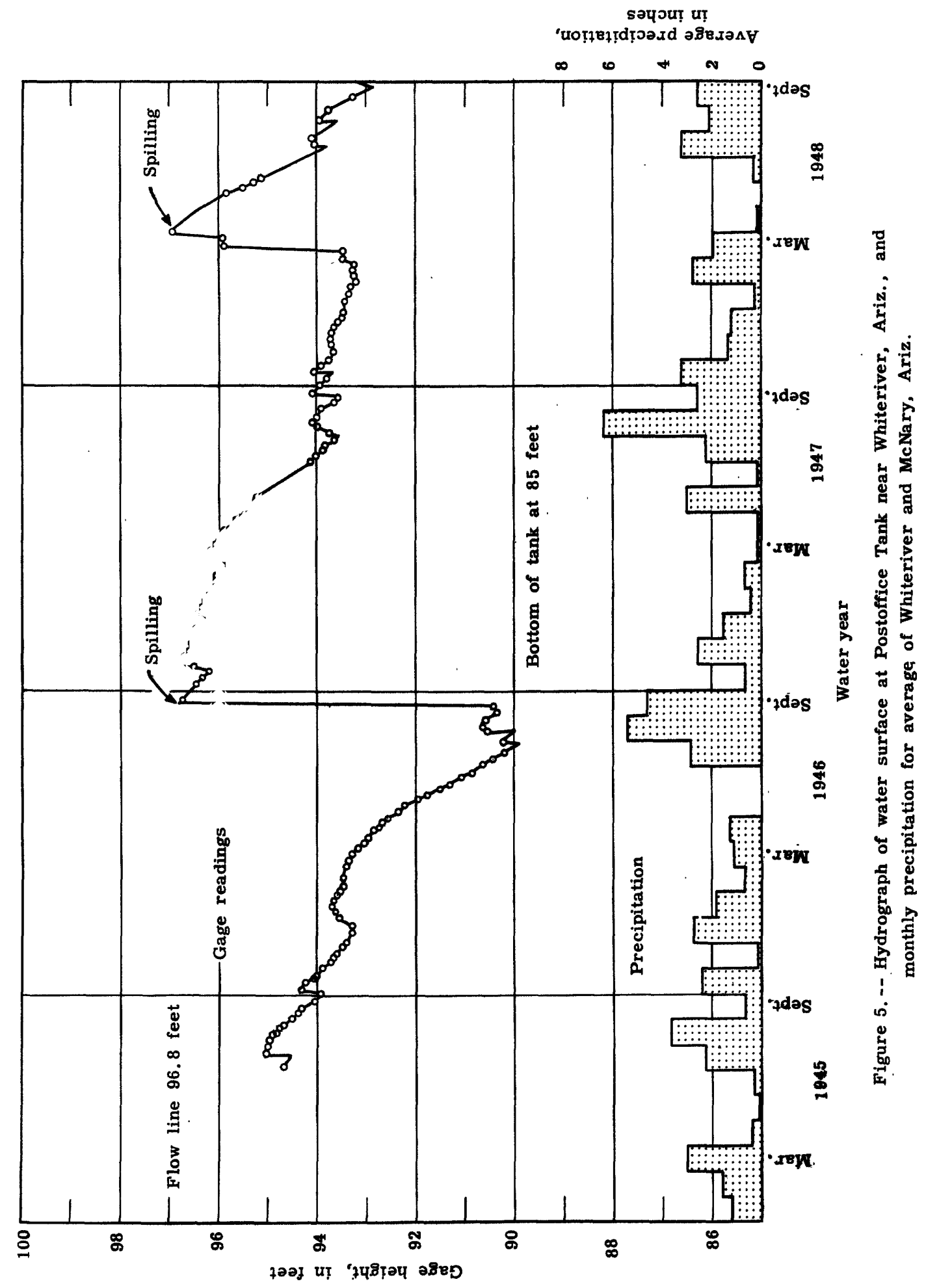




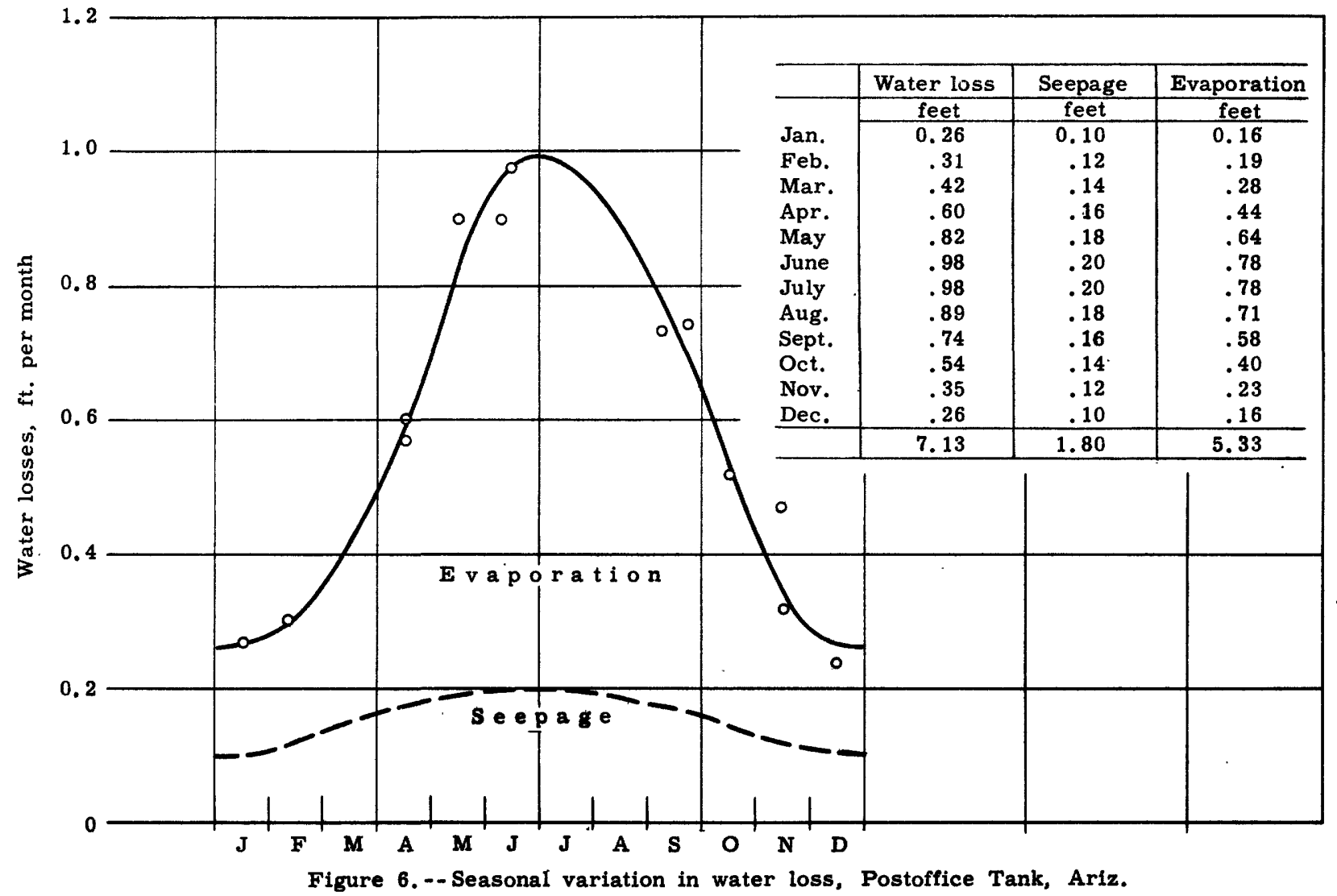

perlods when the water level in the reservolr rises slowly or is quite stable (as in January 1946 when 1 t was indicative of slow contribution from snowmelt)..

The analysis is begun by first considering those dry periods in which it is obvious that no runoff occurred. The quant1 ty $P-\Delta \mathrm{H}$ in such perlods is equal to the water Iosses-1.e., seepage and evaporation ( $s \theta \theta$ table 1 ).

F1gure 6 presents a hydrograph showing the seasonal varlations in the water loss. The graph shows that water losses range from a high of 1 foot per month in midsummer to a low in winter of about 0.25 foot per month. The major cause of the seasonal varlation in water loss is evaporation. Except for the effects of changes in viscosity due to changes in water tempereture, seepage should be falriy uniform during the year in reservolrs with perennial water.

F1gure 7 shows a graphlc study of the water losses during dry perlods taken from table 1 plotted agalnst evaporation as measured in a class-A pan at sierra Ancha (55 miles west), the nearest place where such observations are

Table 1.--Dry perlods, Postofflce Tank $[T=$ trace. $]$

\begin{tabular}{|c|c|c|c|c|c|}
\hline Period & $\begin{array}{l}\text { Mean gage } \\
\text { he1ght }\end{array}$ & $\begin{array}{l}\text { Change } \\
\text { In water } \\
\text { level }\end{array}$ & Prectp1 tation & Water losses & $\begin{array}{c}\text { Pan evaporation } \\
\text { at } \\
\text { slerra Ancha }\end{array}$ \\
\hline & (feet) & $\begin{array}{c}\text { (ft per } \\
\text { month) }\end{array}$ & $($ feet $)$ & $\begin{array}{l}\text { (ft per } \\
\text { month) }\end{array}$ & $\begin{array}{l}\text { (ft per } \\
\text { month) }\end{array}$ \\
\hline $\begin{array}{l}\text { Sept. 8-Oct. 2, } 1945 \\
\text { Nov. } 1945 \\
\text { Apr. } 1946 \\
\text { May } 1946 \\
\text { June } 1946 \\
\text { Oct. } 8-22,1946 \\
\text { Nov. } 1946 \\
\text { Jan. } 1947 \\
\text { Jan. 30-Feb. 25, } 1947 \\
\text { Apr. 1947 } \\
\text { Sept. 2-16, 1947 } \\
\text { Dec. 2-24, 1947 } \\
\text { May 15-June 9, } 1948\end{array}$ & $\begin{array}{l}94.3 \\
93.7 \\
92.8 \\
92.1 \\
91.2 \\
96.3 \\
96.6 \\
96.3 \\
96.0 \\
95.7 \\
93.75 \\
93.6 \\
95.5\end{array}$ & $\begin{array}{l}-0.74 \\
=.47 \\
=.50 \\
=.90 \\
=.88 \\
=.52 \\
=.24 \\
=.26 \\
=.88 \\
=.56 \\
=.73 \\
=.24 \\
=.80\end{array}$ & $\begin{array}{l}0 \\
0 \\
.010 \\
T \\
T \\
T \\
.08 \\
.01 \\
.02 \\
.00 \\
0 \\
0 \\
.01\end{array}$ & $\begin{array}{l}0.74 \\
.47 \\
.60 \\
.90 \\
.98 \\
.52 \\
.32 \\
.27 \\
.30 \\
.56 \\
.73 \\
.24 \\
.91\end{array}$ & $\begin{array}{l}0.65 \\
.30 \\
.60 \\
.76 \\
.94 \\
.48 \\
.22 \\
.16 \\
.22 \\
.57 \\
.70 \\
.18 \\
.85\end{array}$ \\
\hline
\end{tabular}


made. The points are fairly consistent and define a straight line that shows a water loss of 0.1 foot per month when pan evaporation $1 \mathrm{~s}$ zero. This value very likely represents a minImal rate of seepage from Postoffice Tank during the winter season. To the extent that the rate of seepage would vary with the water viscosity, the maximal rate of seepage, in midsummer, should be about 1.8 times the minimal rate. Figures 6 and 7 show this suggested segregation of the water losses into evaporation and seepage. The total annual evaporation is shown as about 5.3 feet, 85 percent of that from the evaporation pan at Sierra Ancha.

The data in table 1 indicate no appreclable effect of reservolr stage or depth of water on water losses. This is not to be interpreted as a general conclusion, although it may be fairly true of reservolrs with perennial water supply and limited range in water-level fluctuation. It may be noted that the hydrograph of Black Hills Tank (f1g. 2) shows a substantial lessening in the rate of water loss with drop in stage.

The graph on figure 7 is a basic relationshlp for computation of the recharge to postofflce Tank. The sum of an observed change in stage and the rate of depletion as controlled by water losses, Indicated by the graph, must be attributed to recharge; thus $\Delta H+I=R / A+P$, where I equals the water losses. When weter level remalns stationary $(\Delta H=0)$, then water losses are balanced by recharge; when water level drops at a rate equal to losses, then recharge is zero.

The computations of recharge and runoff to Postoffice Tank by months are given in table 2 for the period of useful record, August 1945 to september 1848. The 1 tems in this tablo are zenerally self-explanatory. The recharge to the tank is calculated from the formula $\Delta H+I$, where I is total water los as determined from figure 7. The term $\Delta H$ is net change in water level as determined from the stage record. The recharge in feet multiplied by the mean watersurface area, corresponding to the monthly mean gage helght (see f1g. 4), equals recharge in acre-feet. The munoff into the reservols is equal to the recharge minus the precipltation on the water surface. Flgure 8, p. 11, shows precipitation as observed at McNary and Whiteriver (the nearest regular rain-gage stations) plotted against recharge to Postoffl ce Tank. It shows that the computed recharge in feet is always greater than the preclpitation, the excess increasing with precipitation. The excess, of course, represents the runoff into the tank from the contributory drainage area. The amount of runoff is highly variable. A satisfactory definition of a rainfall-munoff relationship would require better rainfall data.

The reservol r overflowed on Sept. 17, 1946 , and from March 31 to April 1, 1948. The volume of splil in acre-feet has been calculated from the following formula, besed on normel shapes of flood hydrographs: $Q$ times total lag divided by 6 . $Q 1 \mathrm{~s}$ peak rate of outflow in cublc feet per second, as calculated from the peak stage used in a broad-crested-weir formula applied to the spillway cross section; thus $Q=2.5 \mathrm{LH}^{3} / 2$ where I is length of spillway in feet, and H 1 s maximum depth of water over splilway, in feet. Total lag is the sum of the detention time, in hours, of the sur-

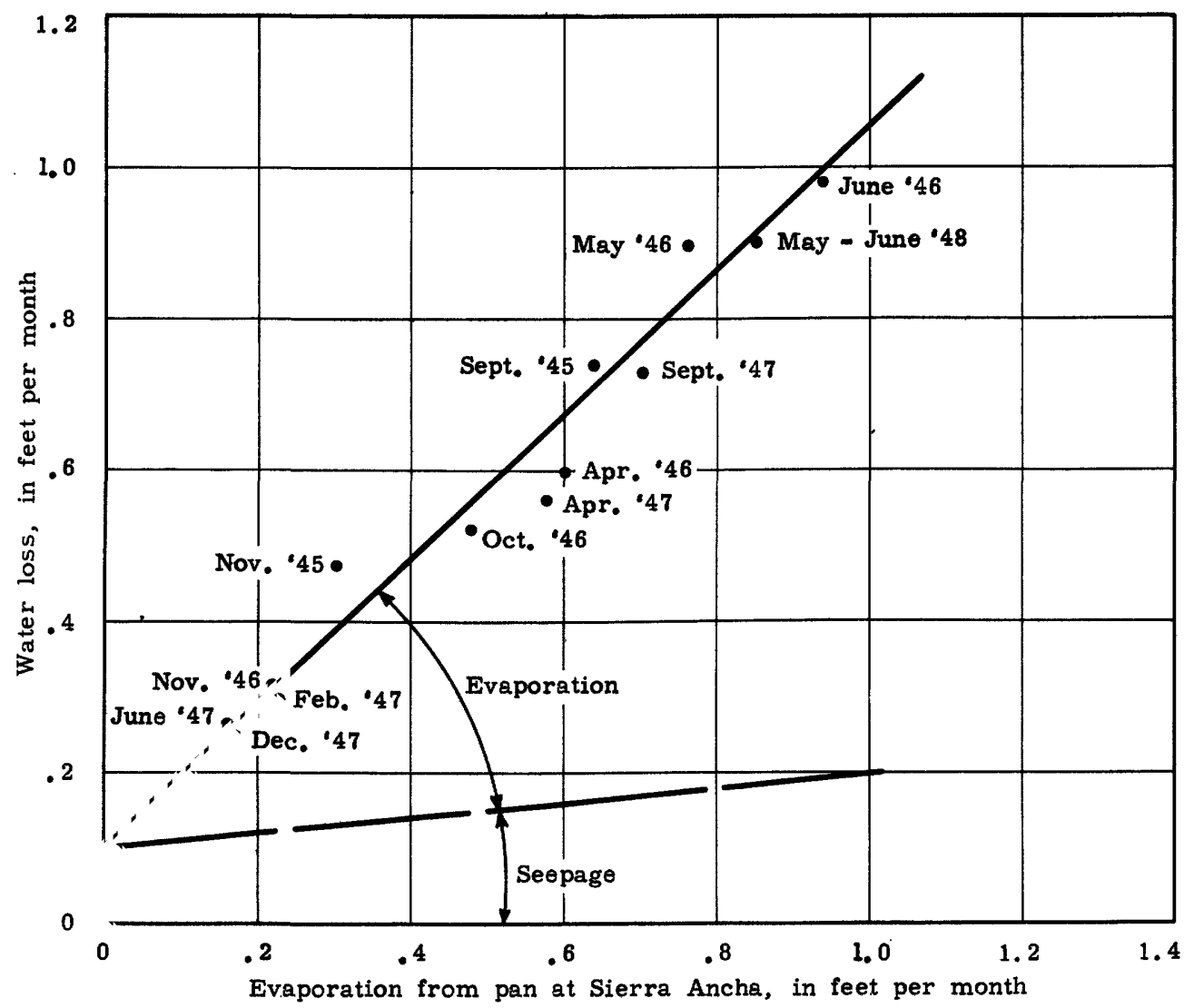

Figure 7.-- Evaporation and seepage from Postoffice Tank, Ariz. 
Table 2.--Computatione of recharge and runoff, Postoffice Tank near Whiter1ver, Arlz. $[T=\operatorname{trac\theta }]$

\begin{tabular}{|c|c|c|c|c|c|c|c|c|c|c|}
\hline \multirow[t]{2}{*}{ Date } & \multirow{2}{*}{$\begin{array}{l}\text { Ga ge hel ght } \\
\text { ond of } \\
\text { period } \\
\text { (feet) }\end{array}$} & \multirow{2}{*}{\begin{tabular}{|c|} 
Mean gage \\
he1 ght
\end{tabular}} & \multirow{2}{*}{$\frac{\begin{array}{c}\text { Change of } \\
g^{a} g^{\circ} \text { helght }\end{array}}{\text { (fest) }}$} & \multirow{2}{*}{$\begin{array}{l}\text { Proclp1- } \\
\text { tation } \mathrm{g} / \\
\text { (feet) }\end{array}$} & \multirow{2}{*}{\begin{tabular}{|l}
$\begin{array}{l}\text { Water } \\
\text { loss }\end{array}$ \\
feet)
\end{tabular}} & \multirow{2}{*}{$\begin{array}{c}\text { Mean sur- } \\
\text { face area } \\
\text { (acres) }\end{array}$} & \multicolumn{2}{|c|}{ Recharge } & \multicolumn{2}{|c|}{ Runor } \\
\hline & & & & & & & (feet) & $\begin{array}{l}\text { (erere- } \\
\text { feot) }\end{array}$ & (feet) & $\begin{array}{l}\text { (erore) } \\
\text { feet) }\end{array}$ \\
\hline $\begin{array}{l}1945 \\
\text { July } \\
\text { Aug: } \\
\text { Sept. } \\
\text { lotal }\end{array}$ & $\begin{array}{l}95.00 \\
94.62 \\
93.82 \\
\end{array}$ & $\begin{array}{l}94.8 \\
94.3 \\
\end{array}$ & $\begin{array}{r}-0.38 \\
-\quad .70 \\
\end{array}$ & $\begin{array}{r}0.18 \\
.31 \\
.05 \\
\end{array}$ & $\begin{array}{r}0.83 \\
.80 \\
\end{array}$ & $\begin{array}{r}0.52 \\
.47 \\
\end{array}$ & $\begin{array}{r}0.45 \\
.10 \\
\end{array}$ & $\begin{array}{r}0.23 \\
.05 \\
.288\end{array}$ & $\begin{array}{r}0.14 \\
.05 \\
\end{array}$ & $\begin{array}{r}0.07 \\
.02 \\
.09\end{array}$ \\
\hline $\begin{array}{l}\text { Oct. } \\
\text { Nov. } \\
\text { Dec. }\end{array}$ & $\begin{array}{l}93.89 \\
93.42 \\
93.55\end{array}$ & $\begin{array}{l}94.1 \\
93.7 \\
93.4\end{array}$ & $\begin{array}{r}-.03 \\
-.47 \\
+.13\end{array}$ & $0_{.23}^{.21}$ & $\begin{array}{l}.52 \\
.40 \\
.28\end{array}$ & $\begin{array}{l}.46 \\
.43 \\
. .41\end{array}$ & $0^{.48}$ & $0_{.27}^{.23}$ & $0_{.18}^{.28}$ & $0^{.23}$ \\
\hline $\begin{array}{l}\text { l946 } \\
\text { Jan. } \\
\text { Feb. } \\
\text { Mar. } \\
\text { Apr. } \\
\text { May } \\
\text { June } \\
\text { July } \\
\text { Aug. } \\
\text { Sept. }\end{array}$ & $\begin{array}{l}93.55 \\
93.40 \\
93.08 \\
92.58 \\
91.68 \\
90.70 \\
90.26 \\
90.42 \\
96.58 \\
\end{array}$ & $\begin{array}{l}93.6 \\
93.5 \\
93.3 \\
92.8 \\
92.1 \\
91.2 \\
90.3 \\
90.5 \\
93.3 \\
\end{array}$ & $\begin{array}{r}0 \\
-\quad .15 \\
-.32 \\
-.50 \\
-.90 \\
-.98 \\
-.44 \\
+.16 \\
+6.16 \\
\end{array}$ & $\begin{array}{l}.16 \\
.06 \\
.10 \\
.10 \\
\mathrm{~T} \\
\mathrm{~T} \\
.23 \\
.45 \\
.39 \\
\end{array}$ & $\begin{array}{r}.24 \\
.34 \\
.46 \\
.70 \\
.86 \\
1.04 \\
.93 \\
.74 \\
.68 \\
\end{array}$ & $\begin{array}{l}.43 \\
.42 \\
.40 \\
.37 \\
.34 \\
.29 \\
.24 \\
.26 \\
.40 \\
\end{array}$ & $\begin{array}{r}.24 \\
.19 \\
.14 \\
.20 \\
0 . \\
.06 \\
.49 \\
.90 \\
6.84 \\
\end{array}$ & $\begin{array}{r}.10 \\
.08 \\
.06 \\
.07 \\
0.02 \\
.02 \\
.12 \\
.23 \\
2.74 \\
\end{array}$ & $\begin{array}{l}.08 \\
.13 \\
.04 \\
.20 \\
0.06 \\
.06 \\
.26 \\
.45 \\
6.45 \\
\end{array}$ & $\begin{array}{r}.03 \\
.06 \\
.02 \\
.04 \\
0 \\
.02 \\
.06 \\
.12 \\
.28 \\
\end{array}$ \\
\hline Total & \multicolumn{7}{|c|}{1846 water year } & 3.82 & & 3.35 \\
\hline $\begin{array}{l}\text { Oct. } \\
\text { Nov. } \\
\text { Dec. }\end{array}$ & $\begin{array}{l}96.72 \\
96.48 \\
96.38\end{array}$ & $\begin{array}{l}96.4 \\
96.6 \\
96.4\end{array}$ & $\begin{array}{l}+.14 \\
-.24 \\
-.10\end{array}$ & $\begin{array}{l}.12 \\
.08 \\
.13\end{array}$ & $\begin{array}{l}.52 \\
.32 \\
.30\end{array}$ & $\begin{array}{l}.60 \\
.62 \\
.60\end{array}$ & $\begin{array}{l}.66 \\
.08 \\
.20\end{array}$ & $\begin{array}{l}.40 \\
.05 \\
.12\end{array}$ & $0^{.54}$ & $0^{.32}$ \\
\hline $\begin{array}{l}1947 \\
\text { Jan. } \\
\text { Feb. } \\
\text { Mar. } \\
\text { Apr. }\end{array}$ & $\begin{array}{l}96.14 \\
96.20 \\
96.00 \\
95.44\end{array}$ & $\begin{array}{l}96.3 \\
96.0 \\
96.1 \\
95.7\end{array}$ & $\begin{array}{r}-.24 \\
+\quad .06 \\
-.20 \\
-.56\end{array}$ & $\begin{array}{l}.01 \\
.10 \\
.01 \\
.01\end{array}$ & $\begin{array}{l}.26 \\
.38 \\
.47 \\
.66\end{array}$ & $\begin{array}{l}.60 \\
.58 \\
.59 \\
.56\end{array}$ & $\begin{array}{l}.02 \\
.44 \\
.27 \\
.10\end{array}$ & $\begin{array}{l}.01 \\
.25 \\
.16 \\
.06\end{array}$ & $\begin{array}{l}0 \\
.34 \\
.26 \\
.09\end{array}$ & $\begin{array}{l}0 \\
.20 \\
.15 \\
.05\end{array}$ \\
\hline & 94.14 & 95.2 & -1.30 & .26 & 1.72 & .53 & .42 & .22 & .16 & .09 \\
\hline $\begin{array}{l}\text { July } \\
\text { Aug. } \\
\text { Sept. }\end{array}$ & \begin{tabular}{|l|}
93.64 \\
93.94 \\
93.96 \\
\end{tabular} & $\begin{array}{l}93.9 \\
83.9 \\
83.9 \\
\end{array}$ & $\begin{array}{r}-.50 \\
+.30 \\
+.02 \\
\end{array}$ & $\begin{array}{l}.27 \\
.53 \\
.22 \\
\end{array}$ & $\begin{array}{l}.99 \\
.80 \\
.76 \\
\end{array}$ & $\begin{array}{l}.44 \\
.44 \\
.44 \\
\end{array}$ & $\begin{array}{r}.49 \\
1.10 \\
.78 \\
\end{array}$ & $\begin{array}{l}.22 \\
.48 \\
.34 \\
\end{array}$ & $\begin{array}{l}.32 \\
.57 \\
.56 \\
\end{array}$ & $\begin{array}{r}.14 \\
.25 \\
.25 \\
\end{array}$ \\
\hline \multicolumn{8}{|c|}{ Total 1947 water year } & 2.31 & & 1.49 \\
\hline $\begin{array}{l}\text { Oct. } \\
\text { Nov. } \\
\text { Dec. }\end{array}$ & $\begin{array}{l}93.78 \\
93.71 \\
93.47\end{array}$ & $\begin{array}{l}93.9 \\
93.7 \\
93.6\end{array}$ & $\begin{array}{l}-.18 \\
-.07 \\
-\quad .24\end{array}$ & $\begin{array}{l}.27 \\
.13 \\
.04\end{array}$ & $\begin{array}{l}.55 \\
.30 \\
.28\end{array}$ & $\begin{array}{l}.44 \\
.43 \\
.43\end{array}$ & $\begin{array}{l}.37 \\
.23 \\
.04\end{array}$ & $\begin{array}{l}.16 \\
.10 \\
.02\end{array}$ & $0^{.10}$ & $0^{.04}$ \\
\hline $\begin{array}{l}2948 \\
\text { Jan. } \\
\text { Feb. } \\
\text { Mar. }\end{array}$ & $\begin{array}{l}93.22 \\
93.50 \\
96.96\end{array}$ & $\begin{array}{l}93.4 \\
93.3 \\
95.2\end{array}$ & $\begin{array}{r}-.25 \\
+.28 \\
+3.46\end{array}$ & $\begin{array}{l}.02 \\
.23 \\
.16\end{array}$ & $\begin{array}{l}.31 \\
.30 \\
.33\end{array}$ & $\begin{array}{l}.41 \\
.40 \\
.53\end{array}$ & $\begin{array}{r}.06 \\
.58 \\
3.79\end{array}$ & $\begin{array}{r}.02 \\
.23 \\
2.02\end{array}$ & $\begin{array}{r}.04 \\
.35 \\
3.63\end{array}$ & $\begin{array}{r}.02 \\
92.14\end{array}$ \\
\hline $\begin{array}{l}\text { Apr.) } \\
\text { May ; }\end{array}$ & 95.40 & 96.2 & -2.56 & .01 & 1.60 & .58 & .04 & .02 & .03 & .02 \\
\hline $\begin{array}{l}\text { June } \\
\text { Julv }\end{array}$ & 93.9 & 94.5 & -1.50 & .30 & 2.10 & .48 & .60 & .36 & .30 & .14 \\
\hline $\begin{array}{l}\text { Aug. } \\
\text { Sept. }\end{array}$ & $\begin{array}{r}93.59 \\
93.14 \\
\end{array}$ & $\begin{array}{l}93.8 \\
93.3 \\
\end{array}$ & $\begin{array}{r}-.31 \\
-.45 \\
\end{array}$ & $\begin{array}{r}.18 \\
.13 \\
\end{array}$ & $\begin{array}{r}.85 \\
.80 \\
\end{array}$ & $\begin{array}{l}.44 \\
.40 \\
\end{array}$ & $\begin{array}{l}.54 \\
.35 \\
\end{array}$ & $\begin{array}{r}.27 \\
.14 \\
\end{array}$ & $\begin{array}{l}.36 \\
.23 \\
\end{array}$ & $\begin{array}{r}.16 \\
.09 \\
\end{array}$ \\
\hline Tota & I 1948 water & year & & & & & & 3.23 & & 3.15 \\
\hline
\end{tabular}

a Mean of Whiteriver and McNary preclpitation: $b$ Includes overflow.

charge (volume above the splilway creat) in the reservolr and that of the drainage besin. The detention time of the reservolr surcharge Is computed from the formula $12 \mathrm{~s} / \mathrm{Q}$, where $\mathrm{s}$ is the maximum volume in temporary storage above the spillway-crest level in acre-feet, and $Q$ is peak rete of outflow in ouble feet per second as computed previously. Detention time of the drainage basin in hours is estimated as equal to the square root of the dralna ge area in square miles.

For Postoffice Tank the detention time of the reservolr surcharge 10 estimated to be 12 hours and that of the drainage basin 0.5 hour.
The splilage was therefore estimated to be 0.2 acre-foot in 1946 and 0.6 acre-foot in 1948. The annual runoff Into Postofflce Tank was as follows:

$\begin{array}{cc}\text { Water year } & \text { Acre-feet } \\ 1946 & 3.35 \\ 1947 & 1.49 \\ 1948 & 3.15\end{array}$

The 3-year average munoff is 2.66 acre-feet, or 8.2 acre-feet per square mile. Because of the slow rate of sedimentation no repeat capac1ty survey was made. 


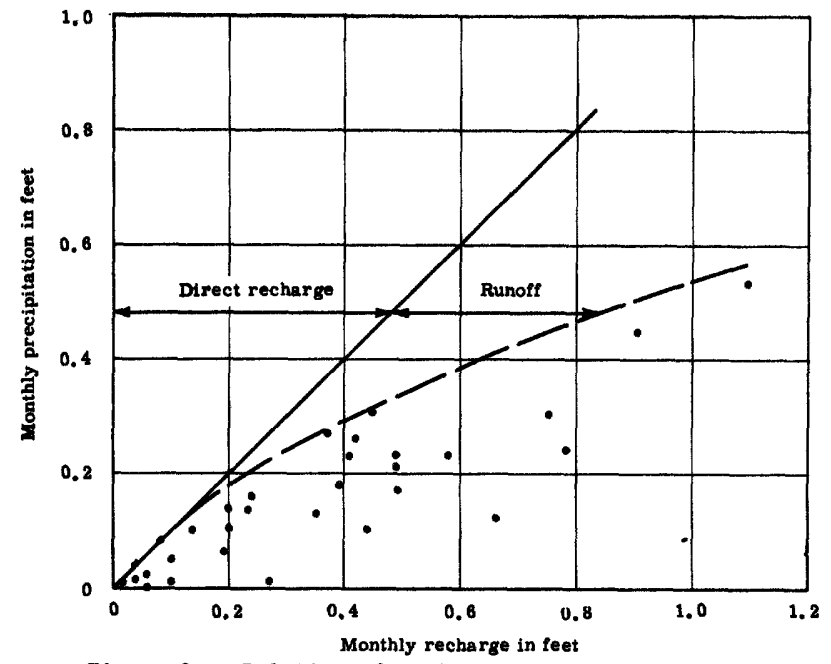

Figure 8.-- Relation of monthly recharge to precipitation, Postoffice Tank, Arlz

\section{ANNOAL RUNOFF}

The annual mnoff at the reservolrs studied, as listed in columns 20 and 21 of table 3 , ranged from 2 to 37 acre-feet per square mile, w1 th a general average of about 9 acre-feet. The amount of runoff that a basin w11l produce depends on the amount and intensity of precipitation, the soll, the geology, and other aspects of the terrain. Adequate information is not at hand for evaluating the effects of each of these factors. An estimate of the munoff from a catchment area can be made from the range noted and by comparison with simliarly situated drainage basins.

Ordinarily, for different drainage basins, one may associate the major part of the variations in mean annual munoff with variations In climate. The munoff values are typical of those that might be expected in semiarid and arid regions, but an examination shows that factors other than climatic are operative. For example, the climatic setting of Black Hilis Tank is considerably more arid than that of Postoffice Tank, yet each reservolr has about the same annual manoff per unit of drainage area. In such cases the differences might be attributed to the geologic characterlstics of the drainage basins. The munoff into Black H1lis Tank appears high because of the large flow in 1948. The arlalty at Black Hills Tank is evident in the year to year varlablilty of the runoff, compared with that into Postoffice Tank.

The high runoff into Beautiful Valley Tank may be due in part to low-1nfiltration capacity of the shale bedrock underlying 1 ts drainage basin. The low runoff into Clay Tank in the Hualapal Indian Reservation may be due to the many cracks and fissures in the I1mestones that Ile at the surface over most of this drainage basin.

Arlzona had a general drought during the perlod of these investigations. Because of the drought, which seemed to be most intense in the Hualapal Indian Reservation, general storms were infrequent, but local convectional storms occurred sporadically. The chance occum rence of summer storms explains, it is believed, most of the diversity in munoff shown by the records. A continuation of these ob- servations should average out most of the erratic effects of the desert climate, so that the influence of general climatic and terrain factors may be discerned.

Nevertheless, diversity in drainage besins as small as these is to be expected. The dif ferences appear to be nearly a great between basins as between years. This diversity indicates that more meaningful information can be obtalned from a large number of observations under widely different terrain and climatic conditions than from few precise records for long periods at a few points.

\section{Seasonal distribution of recharge}

. At reservolrs below 5,000-foot altitude, the records of water level show that recharge occurred in 2.25 months of the year on the average. The distribution of these months (fig. 9A) shows that perlods of recharge are heavily grouped during July to October.

At reservolrs above 5,000 feet, the frequency of recharge averaged 3.0 months per year, somewhat greater than at the lower levels. However, as shown on figure $9 B$, there is less seasonal contrast between winter and summer. The frequency of summer. recharge at these higher levels 18 not slgnificantly less, but the major difference in recharge distribution is the added occurrence of winter rainfall and snowmelt.
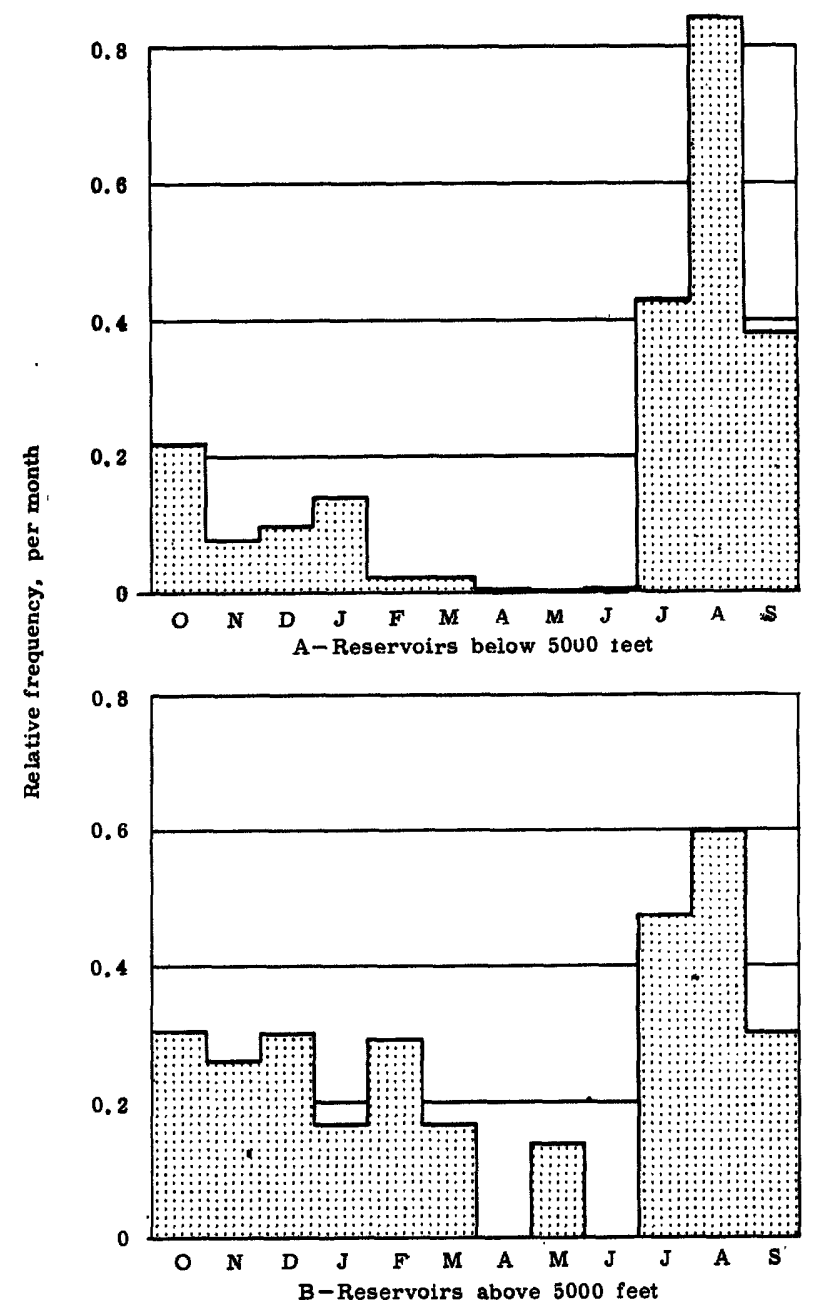

Figure 9.-- Monthly distribution of recharge. 


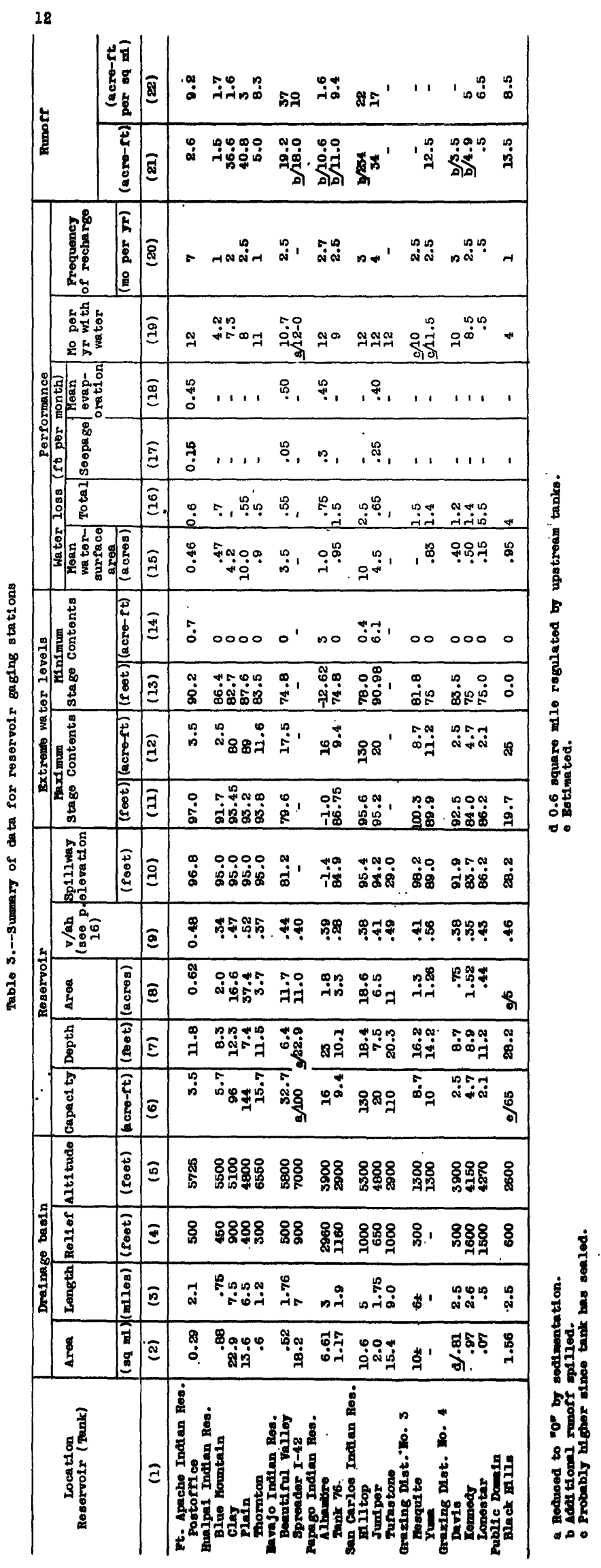




\section{RESERVOIR WATER IOS3ES}

Evaporation and seepage are the two chlef causes of depletion of the water in a stockwater reservolr. Colloctively they are termed water losses. Thls term is quite apt as applied to the stnck-water supply, although the water that seeps from a reservolr may reappear in part as stream flow to support stream-bank vegetation or in ways beneflcial to downstream water users.

The methods of determining the retes of losses, as given in table 3 , a re explained in a previous section of this report. Rates of loss ranged from 0.5 foot to $\mathrm{as}$ much as 5 feet per month. Only four reservolrs had records of water level adequate for separation of water loss into evaporation and seepage. Evaporation rates averaged 0.4 to 0.5 foot per month ( 4.8 to 6.0 feet per year). These $\mathrm{fig}$ ures are probably representative, and seepage can be estimated from the difference between the total water $108 \mathrm{~s}$ and an evaporation rate of 0.45 foot per month. For most of the reservolrs studied, the rate of evaporation loss is the controlling factor in their performance, but as shown in table 3 , there are several reservolrs for whlch the seepage rate greatly exceeds evaporation.

The rates of seepage as determined from analyses of the water-level records (table 3 ) are general averages. Detalled examination of recession hydrographs shows that seepage rates are varlable. Some discussion has al ready been made of the effects of seasonal changes in water temperature upon possible changes in seepage rate: One of the most marked characteristics of hydrographs is the high initial rate of recession immediately after a rise in stage followed by a lessening in rate as the water level recedes. When recharge ralses the water level in a reservolr, some water is absorbed in bank wetting. The rate of percolation 1s initially high while the dry soll absorbs water. On wetting, the clay particles of the soli swell and the rate of percolation dimin1shes. With recession of the reservolr level, the exposed land surface dries out, and the clays again shrink. The drying out represents a loss of the water that was absorbed in bank wetting. Those reservolrs that have large fluctuations in water level, separated by long periods of drying out, appear to have greater net seepage losses than those that have more stable water levels. These losses are particularly algnificant in reservolrs that have gently sloping sides. Such reservolrs are equaliy unsatisfactory because of evaporation losses.

The rate of seepage also varies for the following reasons which are related to position of water level: (1) Decreases in hydraulic head wi th recession in water level, and (2) the greater permeability of bed materials In the higher parts of a reservoir than of the thicker muds in the bottom of the reservolr.

In view of the still fragmentary nature of the records of water level in stock-water reservolrs, detalled investigation of variation in seepage losses does not appear feasible at this time. However, new techniques a re being tried for determination of rate of seepage and evaporation.
The problem is to determine how much of an observed recesalon in water level during dryweather pertods is due to seepage and how much is due to evaporation. The principles employed in the separation are: (1) Bvaporation varies in response to meteorologic controls, and (2) seepage is relatively uniform at a given tage and season. The relative proportions of evaporation and seepage are therefore variable.

In the annual cycle, loss by evaporation from shallow lakes reaches maximum in summer and minimum in winter. Figure 6 shows the seasonal variation in rate of water loss (rate of recession in absence of recharge) from Postoffice Tank. The rate of recession ranged from a maximum of 0.98 foot per month in June and July to a minimum of 0.26 foot per month in January. It is ovident that evaporation is the dominant factor in this seasonal variation of water loss. The seasonal varlation was used to estimate the monthly rate of seepage wh1 ch was then deducted from the rate of recession to compute the rate of evaporation.

The diurnal cycle offers a comparable method for separating observed recession rates in seepage and evaporation. In the typlcal diurnal cycle, seepage (In or out) is uniform in rate but evaporation from shallow lakes is generally a maximum in midafternoon and a minimum sometime between midnight and sunrise. The minimum rate of recession approaches the rate of net seepage, according to a similar principle used by White (1932) to estimate rate of recharge from the diurnal transpiration cycle in ground-water level in an observation well.

A more refined technique that suggests 1tself is to measure the rate of recession in water level as precisely as possible during a 24-hour period and to correlate the rate of recession against an expression that combines the meteorologic and wa ter-tempere ture factors that influence evaporation. Observations for this purpose were made at Junlper Tank on June 27-28, 1849, and August 5-6, 1950.

A serles of hourly observations of water level, water temperature, wind speed, and wetand dry-bulb temperatures were made during these two serles. The methods used during the series of observations on August 5-6, 1950, are described below.

(1) Lake stage--measured by a vernier point gage, reading directly to thousandths of a foot. A gage well was provided by a 55 galion oll drum, set offshore in the northern part of the lake in water about $\lesssim .5$ feet deep. The intake was a quarter-inch hole about 18 inches below water surface.

(2) Wet- and dry-bulb temperatures--measured by standard Weathor Bureau type sling psychrometer. Observations were made under the shade of a tractor umbrella, on the northern shore about 6.5 feet above water surface. Check observations showed no detectable difference between temperatures thus measured on the upwind and the downwind sides of lake.

(3) Wind speed--measured by a 3-cup Friez anemometer, mounted about 6.5 feet above water surface. 
(4) Water temperature: (a) Surface water-measured at a point near the well, with bulb just under the surface and shaded from the sun. Check measurements of surface-water temperatures at various points in reservoir showed temperatures varying as much as $2^{\circ}$ higher or lower from that measured at index point. (b) Bottom water--measured by obtaining a sample of bottom water in a 12 -ounce bottle with a slow air leak. Duplicate samples were taken to assure equilibrium between bottle and water. Observations were made in water 4 feet deep. Greatest depth is probably 5.5 feet.

The observations are given in table 4. Averages for 4-hour periods are given for the June 1949 series and 2-hour periods for that of August 1950 when more precise data were obtained.

Generalized hydrographs of retes of change in water level are shown on figure 10. The diumal cycle is well developed in both semes of observations, although more marked in the June 1949 series. The minimum rate in each case was reached chring the hours after midnight.

The minimum rate approaches the rate of seepage to the extent that evaporation during the early morning hours was zero and might be taken as close approxi mation of the seepage rate, were it not that consideration must be given to the possibility of negative evaporation, 1.e., condensation. A closer estimate of seepage might be calculated if allowance is made for the rate of evaporation or condensation, small as the rate might be.

There are several formulas for combining the meteorological factors into an expression for evaporation. A review of these formulas and the theorles upon wht ch they are based is given in a recent report by the U. S. Navy

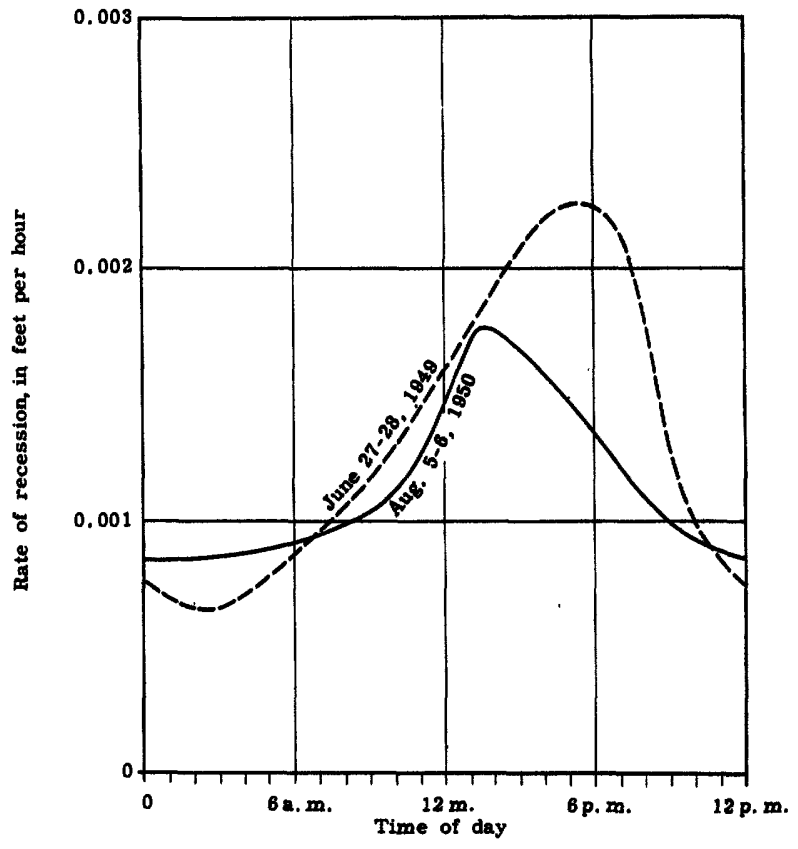

Figure 10.--Diurnal variation in rate of recession in water level.
Electronics Laboratory (Anderson et al., 1950). We are not concerned with a formula for evaporation but rather with an expression that is proportional to evaporation; or more specificaliy one that will reduce to zero when evaporation is zero. For this purpose, use can be made of the expression: $E$ u $3 / 4$ ( $\left.e_{w}-\theta_{a}\right)$, where $u$ is wind speed in miles per hour; $\theta_{w}$ is vapor pressure in inches of mercury, corresponding to temperature of the surface water in the reservolr; and $e_{a}$ is the vapor pressure of the alr, corresponding to the dew point.

An examination of the data in table 4 shows that dew points were generally stable during the periods of observation. Water at the surface showed significant amounts of cooling at night, but rates of wind movement showed the major diurnal change. Most of the variation in rate of recession in water level was assoclated with changes in wind speed. This assoclation is somewhat unfortunate because comparatively little is known about the effect of wind speed upon the rate of evaporation under differing conditions of atmospheric stability, whereas experiments generally confirm that, except for molecular diffusion in the absence of wind, evaporation is proportional to $\theta_{w}$ - ea, the so-called "Dalton difference." Rough calculation, however, Indicates that molecular diffusion is of the order of 0.00005 foot per hour, an amount too small to be considered in this analyols. Therefore, it is permissible to preaume that under field conditions evaporation is zero when wind is zero, a condition that is satiofied by the foregoing expression.

The value of the exponent of the wind speed, $3 / 4$, as orlginally proposed by Millar (1937) for average atmospheric stability, is conflrmed by these observations to the extent that a value of about this olze yields the maximum correlation with the rate of recession in water level. Although a more general analysis would permit variation in the value of the exponent of wind speed in accordance with the degree of stability, a constant exponent is considered sufflciently atisfactory for this study.

The values of the expression $u^{3 / 4}\left(\theta_{w}-\theta_{q}\right)$ are glven in the final column of table 4 and are plotted against the observed rate of recession on figure 11. The points satisfactorily defIne two graphs of equal slope but different intercepts for the two series. We are concerned primarily w1 th these intercepta because they presumably represent the rate of recession when evaporation is zero. The rate of recession then represents seopege. The intercepts on the axis of zero evaporation are 0.00038 foot per hour for the series of June 1948 and 0.00064 foot per hour for the serles of August 1950. The greater seepage in the August 1950 serles 1 s due largely to the feot that the water level then stood fust at the spiliway, 2.3 feet higher than in June 1948 .

The water budget for 24-hour perlods in these two serles is as follows:

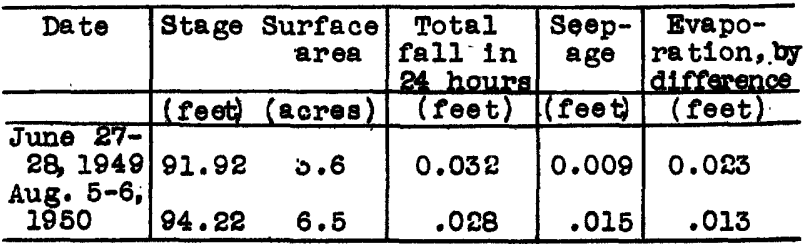




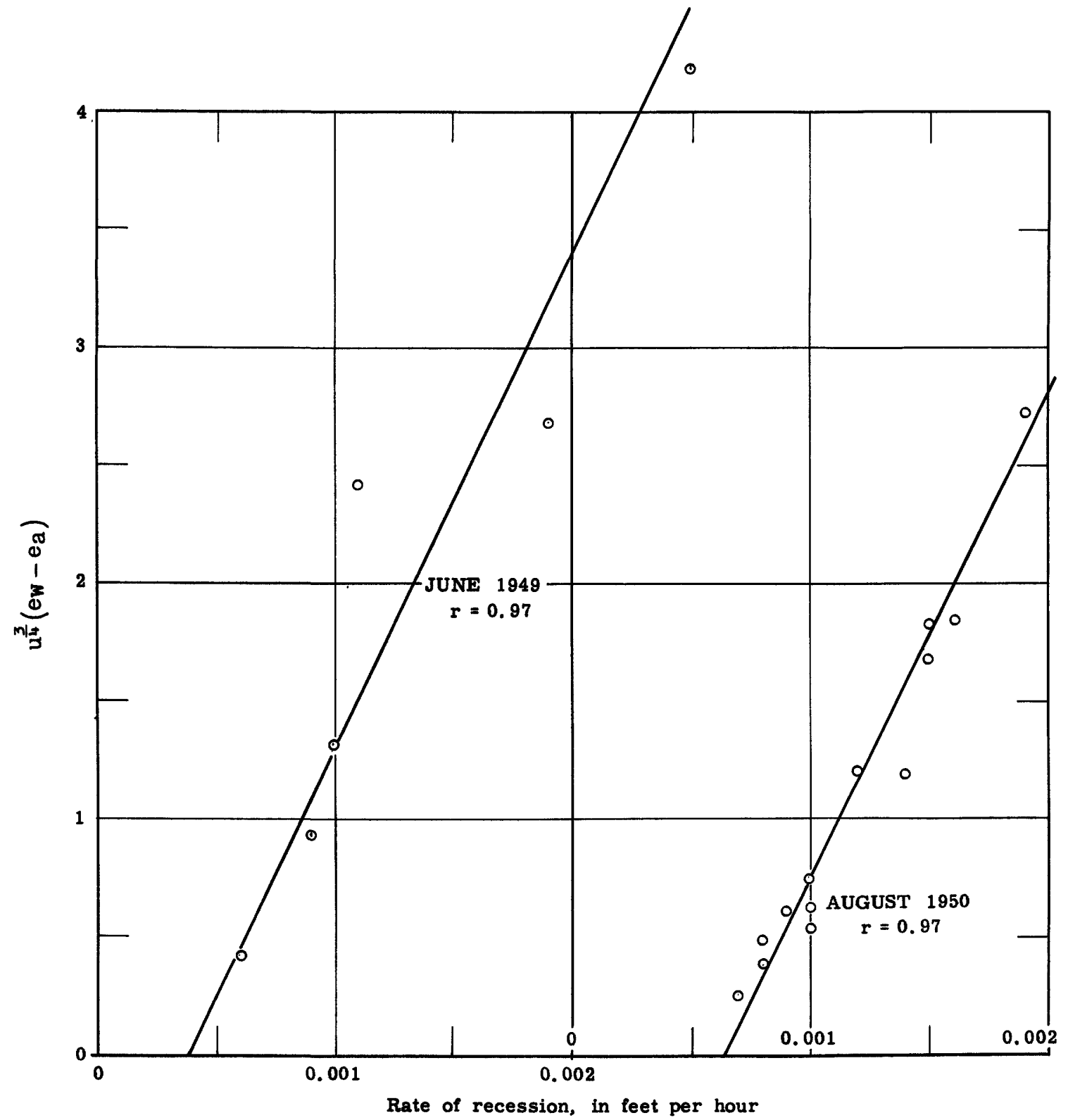

Figure 11. -- Variation in rate recession with $u^{\frac{3}{4}}\left(e_{w}-e_{a}\right)$.

The quantities in acre-feet can readily be determined, if desired, by multiplying the depths by the surface areas in acres on the respective days, as given in the table at the bottom of page 14 .

The analysis of the seasonal variation in the rate of recession for Juniper Tank, by the methods explained in the Postofflce Tank illustration in this report, indicates that the mean rate of seepage of Junfper Tank during the summer months is about 0.32 foot per month, or 0.01 foot per day. This value is within the range indicated by the above analysis of the diurnal cycle. By detalled analysis of the diurnal cycle several times during the year, it should be possible to define the Influence upon seepage of stage, water temperature, and other factors. 
Table 4.--Observations at Juniper Tank

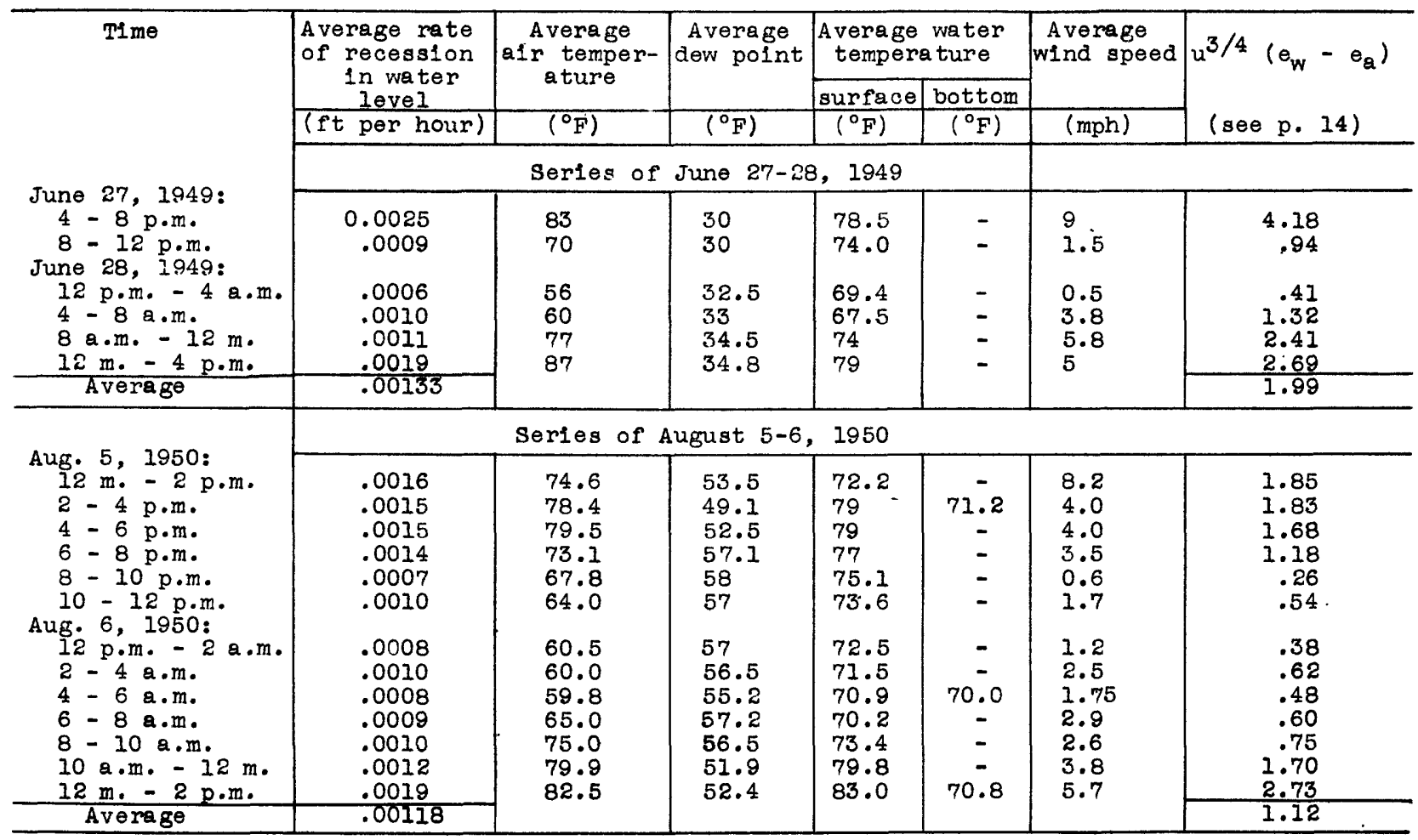

\section{PERFORMANCE}

The results obtained at the reservoir gaging stations as summarized in table 3 are, in general, self-explanatory. The capacitles of the reservoirs studied ranged from 2.1 to 144 acre-feet. In relation to size of drainage area the capacities averaged about 9 acre-feet per square mile. Reservoirs with less capacity then this generaliy spilled one or more times during the perlod of gage readings.

Reservoir shape is indicated by the ratio $\mathrm{v} / \mathrm{ah}$ (see column 9 of table 3 ), where a is the area in acres at spillway level (column $8)$, h the depth in feet from splilway level to bottom of the reservolr (column 7 ), and $v$ the total capacity in acre-feet to splilway level (column 6). This ratio a verages about 0.4 and suggests a rough rule for estimating capacity of a reservolr--capac1ty $=0.4 \times$ area $\mathrm{x}$ depth.

Table 3 Includes a summary of the maximum and minimum water levels and contents during the period of observation, generally 1945-48. About half the reservol rs overflowed and, with few exceptions, every reservolr listed was dry at least once during the perlod of observation. Reservolrs are bullt to hold water between rains. The ideal reservolr contains usable water all year, although in cases of seasonal.use of the range the reservolr need contain water only during seasons when the surrounding range is grazed. As measured by the average number of month's per year durlng which they contalned water, the reservolrs included in this study were falrly successful. Only three had water for less than 6 months, whereas five contalned water the year long.
Depth of water is well recognized as a major criterion in goverming performance of a reservolr; but it is important not to confuse depth of water with depth of reservolr, as many high dams Impound only shallow pools of impermanent weter.

The depth of water in a reservoir, and therefore its performance, is the result of several factors: Volume of inflow; frequency of inflow; rate of 10ss; and depth-area relation of reservoir. A study of these factors in relation to the performance of the reservolins is shown on figure 12. The ordinate represents the average number of months per year that the reservoirs contain water, as given in colurm 19 of table 3 . In the quantity $R / a L, ~ R$ represents the annual munoff in acre-feet (column 21 of table 3), a the mean water-surface area in acres (column 15), and I the mean rate of water lose in acre-feet per month (column 16). The plotted numbers on f1gure 12 indicate the average number of months per year in which recharge occurs (column 20). For most of the reservoirs studied the value of a averaged about 60 percent of the area at the splilway (column 8 of table 3) for reservolrs wl th yearlong supply., and 30 percent for others. The relationship shown on figure 12 can be approximated by the following formula: $\mathrm{p}=(\mathrm{F}-\mathrm{I})+\mathrm{R} / \mathrm{aL}$. The value of $\mathrm{F}$ (average frequency of recharge) ranged from 1 to 3 months per year, so that the carry-over term $\mathrm{R} / \mathrm{aI}$ is the major criterion as to performance. In humld reglons, where recharge occurs more frequently, high performance can be achleved even though the quantity $R / a I$ is low. 


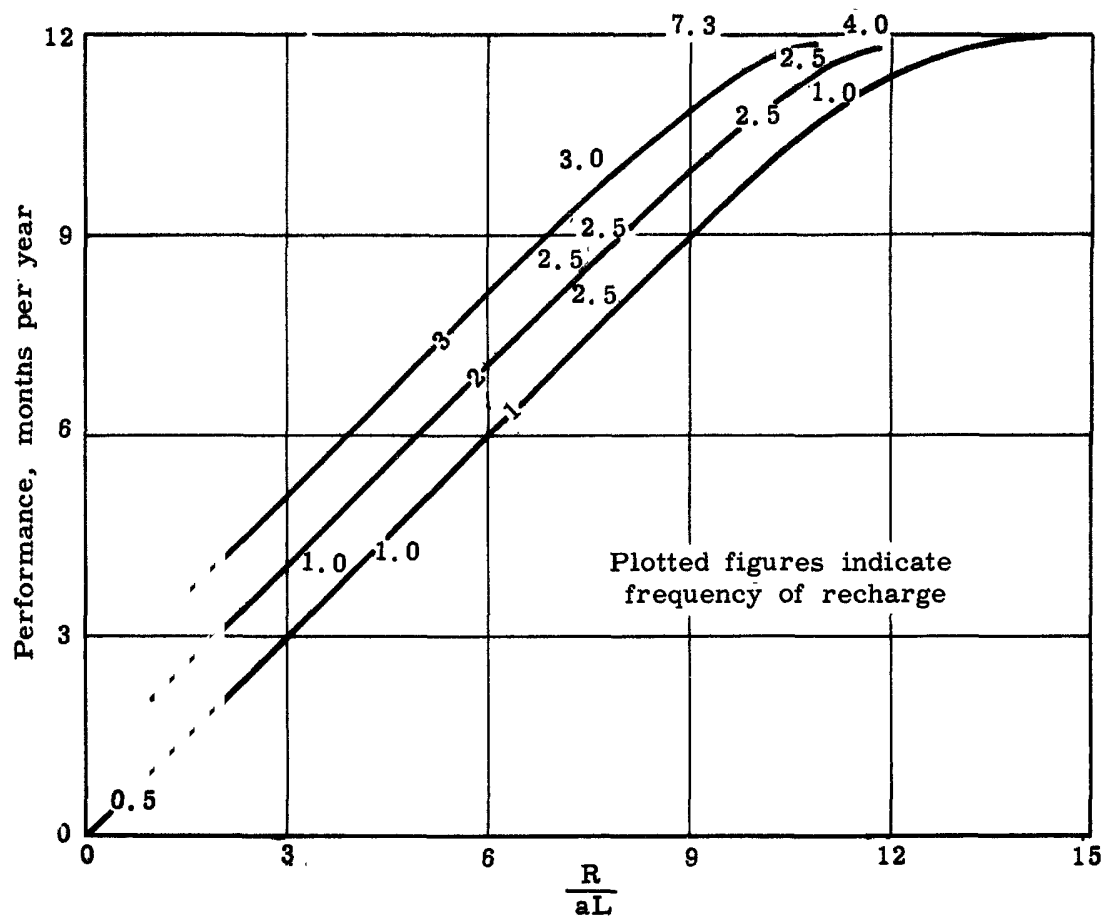

Figure 12. - Relation of performance to runoff, water area, water loss and frequency of recharge.

\section{PRINCIPLES OF RESERVOIR DESIGN}

Unlike an 1rrigation reservolr, the performance of a stock-water reservoir is dependent on depth of water rather than on capacity. The records demonstrate that there is generally little need for a reservoir to have a capacity greater than that necessary to store the mean annual runoff. Providing additional capacity to store the water that would spill in years of extraordinary runoff, according to the evidence obtained, does not thereby provide weter during extended dry periods. Rates of loss are great at high, infrequent stages and losses at such stages may be at the expense of downstream users wi thout necessarily benefiting the stock-water supply. Increasing capacity is generally an uneconomical method of obtalning depth. For example, doubling the capacity in most reservolrs adds only about 35 percent to the depth. Nor does placing reservolrs in tandem, in lieu of a single large reservolr, seem to help; to the contrary, it even increases losses wi thout providing water during dry years. Rate of losses imposes a limit on the amount of carry-over water that can be provided.

The problem is to get sufficlent water depth to carry over a reasonably long dry pertod. For economic reasons, this need not be the longest dry period on record, but 1t must be one that is falriy representative of the dry perlods that are likely to occur. The waterlevel records indicate that. this dry period In Arlzona is rarely longer than 15 months and $1 \mathrm{~s}$ less where recharge occurs more than once a jear. For purposes of design, the dry period in months may be roughly estimated from the formula $15[2 /(F+1)]$, where $F$ is the average frequency of recharge per year. This leads to the important criterion that depth should be at least equal to $15[2 /(F+1)] I$, where I is average rate of weter loss in feet per month--provided that the capacity at this depth does not greatly exceed annual runoff.

Consider the following as an example. Given: $R=15$ acre-feet per year, $I=0.6$ foot per month, and $F=2$ months; required: depth for 12-month performance. Depth needed is $15[2 /(F+1)] I=6.0$ feet. The area-capacity curves for this site shows a surface area of 2.5 acres and a capacity of 6 acre-feet at a 6-foot depth. The mean surface area exposed to loss may be taken as 0.6 of the area at the 6-foot depth. Annual losses would therefore be $(0.6 \times 2.5$ acres) $x 0.6$ foot per month $x 12$ months $=11$ acre-feet. Since there is ample munoff to supply this loss, a 6-foot reservoir should provide 12-months water per year, on the average, until this depth is depleted by sedimentation. Excess water will be spilled.

If runoff were only 3 acre-feet per year there would be some question whether a 6 acrefoot reservoir would be economical at this site, inasmuch as it would be rarely filled. Yearlong water supply could be obtained at this site only through supplementation of depth by excavation of a charco (pit reservolr) such that total capacity at a depth of 6 feet does not exceed the annual manoff, about 3 acrefeet in thls exemple.

The design of a stock-water reservolr requires Information that is not generally a va11able in advance. The data obtained in this invest1 gation, nevertheless, do indicate certain limits that might be observed in order to 
minimize expense without detracting from performance. Some rough miles might be as follows: Depth not less than about 7 feet for a capacity of not more than 5 to 10 acre-feet per square mile of drainage area. Where this depth cannot be obtained within the specified limit of capacity at a natural site, charco pits are necessary. Charco pits constmuted by buflding the dam from materials excavated from the reservolr bottom are desirable in every case provided excavation does not extend into permeable materials. Enough is known (Holtan, 1950) about solls to show that seepage losses may be minImlzed by compacting the bottom materials prior to filling the reservolr. The best material for compaction. is a well-graded mixture of not more than 30 percent or even as little as 5 percent of clay. The bottom should be loosened to a depth of at least 6 inches and then brought to a moisture content of good tilth. The loosened and molstened soll should be compacted by heavy machinery or cattle. The process is about the same as might be followed in bullding a tight dam. In important jobs. the method can be refined and the material made nearly water-tight.

For practical reasons reservolis should have

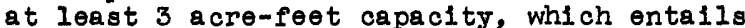
a drainage area of at least 0.6 square $\mathrm{mile}$.
Exceptions might be made in regions of high runoff provided seepage is very low. As reservolrs on large drainage areas tend to involve troublesome amounts of sediment as well as other expensive factors, it appears inadvisable to 1 mpound a wash with a drainage area of more than 15 square miles for a stock-water supply.

\section{REFERENCES CITED}

Anderson, E. R., Anderson, I. J., and Marciano, J. J., 1950, A review of evaporation theory and development of instrumentation, interim report on Lake Mead water-loss investigation: U. S. Navy Electronics Lab. Rept. 159, San Diego.

Holtan, H. N., 1950, Holding water in farm ponds, Soll Cons. Service, U. S. Dept. Agr., SCS-TP-93, $10 \mathrm{pp}$.

Millar, F: G., 1937, Evaporation from free water surfaces: Canadian Meteorological Memolrs, vol. 1, no. 2 .

White, Walter N., 1932, A method of estimating ground-water supplies based on discharge by plants and evaporation from soll: U. S. Geol. Survey Water-Supply Paper 659A. 